\title{
EFFECT OF DENSITY AND FLOWER SIZE ON THE REPRODUCTIVE SUCCESS OF NOTHOSCORDUM GRAMINUM (ALLIACEAE)
}

\author{
EFECTO DE LA DENSIDAD Y TAMAÑO FLORAL SOBRE EL EXITO \\ REPRODUCTIVO DE NOTHOSCORDUM GRAMINUM (ALLIACEAE)
}

\author{
Marco A. Molina-Montenegro ${ }^{1}$ \& Lohengrin A. Cavieres ${ }^{1,2}$ \\ ${ }^{l}$ ECOBIOSIS, Departamento de Botánica, Universidad de Concepción, Casilla 160-C, Concepción, Chile; ${ }^{2}$ Instituto \\ de Ecología y Biodiversidad, Casilla 653, Santiago, Chile. \\ marcmoli@udec.cl
}

\begin{abstract}
The size, form and color are signals used by flowers to attract their pollinators. Large and showy color flowers usually receive higher pollinators visitation rates. According to the optimal forage theory, pollinators would tend to visit flower patches where they obtain the maximum reward regarding the energy expenditure in flower search. In high density patches, flowers are very close each other, hence, flower discrimination by pollinators would tend to be low. In low density patches, however, where the forage effort is greater, larger flowers are usually associated with higher rewards and would receive higher pollinators visitation achieving greater fitness than co-especifics with smaller flowers. In the present study we assessed the effects of flower density and size on the reproductive success (RS) of Nothoscordum gramineum. Four patches of different densities were delimited and the flowers size of the half of individuals at each patch was manually reduced. Results showed that RS was significantly greater in individuals with larger flowers. Additionally, density has a positive effect on RS, especially in large size flowers. Nevertheless, fruition success reached maximum values in patches of intermediate density. Individuals with cut flowers did not varied the RS with the variation of the density, suggesting that flower size is the most important attribute measured as advertisement by pollinators in N. gramineum. Our results do not support the hypothesis that in high density patches, flower displays have low importance.
\end{abstract}

KeYwords: Pollinators visit, floral traits, seed output, fitness.

\section{RESUMEN}

El tamaño, la forma y el color son señales que utilizan las flores para atraer a sus polinizadores. Las flores que presentan un gran tamaño o alta vistosidad reciben una alta tasa de visitas de polinizadores. Según la teoría óptima de forrajeo, los polinizadores tienden a visitar los parches donde disminuyan el esfuerzo del forrajeo y obtengan una mayor recompensa. En parches de la alta densidad las flores están agrupadas, razón por la cual la discriminación entre las flores tendería a ser baja. Sin embargo, en parches de la baja densidad donde el esfuerzo de forrajeo es mayor, flores de mayor tamaño recibirían mayores tasas de visitas de polinizadores y manteniendo un mayor éxito reproductivo que individuos coespecíficos de menor tamaño. En el presente estudio determinamos el efecto de la densidad y del tamaño floral sobre el éxito reproductivo (ER) y el éxito de fructificación (EF) en la especie Nothoscordum gramineum. Cuatro parches de distintas densidades fueron delimitados y el tamaño de las flores de la mitad de los individuos presentes en cada parche fue reducido manualmente. Los resultados demuestran que tanto la ER como EF son significativamente mayores en los individuos con flores más grandes. Demostramos además que la densidad tiene un efecto positivo sobre el ER, principalmente en las flores de mayor tamaño. EF alcanzó valores máximos en los parches de densidades intermedias, disminuyendo en los de mayor densidad. Los resultados sugieren que el tamaño floral fue el atributo medido más importante sobre la adecuación biológica de $N$. gramineum, debido a que los individuos de flores cortadas no respondieron con la variación de la densidad. Nuestros resultados no permiten apoyar la hipótesis que en parches de alta densidad, los rasgos florales tendrían menor importancia, puesto que siempre ER y EF fueron mayores en flores enteras sin considerar la densidad, y las flores cortadas no demostraron un aumento en ER o EF con el aumento de la densidad.

Palabras claves: Visita de polinizadores, rasgos florales, producción de semillas, adecuación biológica. 


\section{INTRODUCTION}

Several studies have reported that the reproductive success of plant individuals increases with population density (Bosch \& Waser 1999, Kato \& Hiura 1999, Brys et al. 2004). In plant species pollinated by insects, this positive relationship between plant density and reproductive success is explained, in part, by increases in pollinator visitation rates (Klinkhamer \& Van der Lugt 2004). According to the optimal forage theory, pollinators will visit those flower patches where they obtain the higher nutritional rewards and the lower cost of flight between individual flowers (Klinkhamer \& Van der Lugt 2004). In patches with high density of flowers, the availability of resources is high (i.e., nectar) whereas the distance between flowers is short. In contrast, in patches with low density of flowers, the amount of resources is low and the distance between flowers is high, which increases the cost of forage for pollinators (Roy 1996). Therefore, patches with high density of flowers would be more frequently visited by pollinators, and hence achieving a higher reproductive success. However, some studies have showed decreases in the reproductive success of individual plants with the increase of the population density, which could be related with increases in intraspecific competition (Pacala \& Silander 1990) and/or inbreeding depression (Mitchell et al. 2004).

Size, form and color of flower are signals used by plants to attract pollinators (Faegri \& Van der Pijl 1971, Neal et al. 1998). Flowers of large size, showy colors and with corollas of contrasting colors are usually more visited than flowers of small size, without showy colors or without contrasting colors in their corollas (Krannitz \& Maun 1991, Roy 1996). According to Cohen \& Shmida (1993) and Robertson \& Macnair (1995), flower signals (e.g., flowers size) would have less importance as advertisement for pollinators in patches with high density of flowers. That is, pollinators will select patches with many flowers and once inside these high density patches, they will not discriminate between flower of different sizes, because the cost of forage between flowers is low (Cavieres et al. 1998). In contrast, in patches with low density of flowers, given that the distance between flowers increases the cost of forage, floral signals (e.g. flower size), would acquire a greater importance as advertisement for pollinators, being a key factor in the decision of forage (Krannitz \& Maun 1991).

It is well known that increases in pollinator's visitation produce increases in seed output (Aizen \&
Feinsinger 1994, Suzuki 2003). Thus, it should be expected that individuals with greater flower sizes have greater seed output than their co-specific with smaller flower sizes in patches with low density of flowers, however this difference should decrease as population density increases. In this study we assessed the effect of flower density and flower sizes in the reproductive success of Nothoscordum gramineum (Sims) P.Beauv. in a coastal evergreen forest of central Chile.

\section{MATERIALS AND METHODS}

\section{Study SITE AND TARGET SPECIES}

Field work was carried out in the Botanical Reserve Pedro del Rio Zañartu ( $\left.36^{\circ} 45^{\prime} \mathrm{S} ; 7^{\circ}{ }^{\circ} 09^{\prime} \mathrm{W}\right)$, located in the peninsula of Hualpén, ca. $15 \mathrm{~km}$ west to the city of Concepción, Chile. Vegetation is characterized by remnant patches of evergreen native forest, dominated by Cryptocarya alba (Molina) Looser (Lauraceae), Aextoxicon punctatum Ruiz et Pav. (Aextoxicaceae), Peumus boldus Molina (Monimiaceae) and Lithrea caustica (Molina) Hook. et Arn. (Anacardiaceae) (Polymeris 1995).

Nothoscordum gramineum (Alliaceae), is a native geophyte perennial herb, that lives in open areas or forest gaps, forming very abundant populations. It grows up to $25 \mathrm{~cm}$ height, has linear and flat leaves of $20 \mathrm{~cm}$ length, and 2 to $3 \mathrm{~mm}$ width. Each individual can produce 5 to 9 flowers, each measuring ca. 8 to $12 \mathrm{~mm}$ length, arranged in five to nine umbellas per individual (Hoffmann et al. 1997).

\section{MANIPULATION OF FLOWERS}

Four patches of $9 \mathrm{~m}^{2}$ each, and with different densities of Nothoscordum gramineum individuals in bloom $\left(1.6,2.3,5.5\right.$ and 9.8 individuals $\left./ \mathrm{m}^{2}\right)$ were delimited. At each patch, fourteen individuals were randomly selected, and the number of flowers per individual was manually reduced to two. In seven of these individuals, flower size was reduced by cutting the tepals to the half. Individuals were left so that would be naturally pollinated. After one month, fruits were collected and transported to the laboratory where the number of seeds that contained each fruit was counted. For each individual we recorded the number of fruits produced, and the number of seeds per fruit in each individual that produced fruits. 
DATA ANALYSES

Reproductive success (RS) was assessed as the number of seeds produced per fruit in each individual that produced fruits. To test the effect of plant density and flower size, an analysis of co-variance (ANCOVA) was performed, where RS was the dependent variable, flower size the independent factor and density as co-variable.

\section{RESULTS}

Overall, percentage of fruit-set was higher in whole flowers (Table I). Both, in whole and cut flowers, the maximum fruition success (FS) was found in patches with intermediate density (Table I).

Regarding the number of seeds per fruit, the highest seed production was observed in the whole flower treatment in the highest population density (Table I). The lower seed production per fruit was registered in plot 2, with an average of 6.9 seeds per fruit. In cut flowers, the highest seed production per fruit was registered in plot 3 , which had a high density of individuals. In contrast, the lowest seed production was registered in plot 1 , which had the lowest population density, and where no seed production occurred (Table I).

TABLE I. Reproductive success (RS), fruit production and fructification success (FS) in Nothoscordum gramineum, under two factors. Individuals with whole flowers (WF) and cut flowers (CF), growing in four patches with different floral densities. \pm S.D. are shown.

TABLA I. Exito reproductivo, producción de frutos y éxito de fructificación en individuos de Nothoscordum gramineum con flores enteras $(\mathrm{WF})$ y flores cortadas $(\mathrm{CW})$ creciendo en cuatro parcelas de diferente densidad floral. \pm D.E. son mostradas.

\begin{tabular}{lcccc}
\hline Site and treatment & $\begin{array}{c}\text { Density } \\
\left.\text { (ind./ } \mathrm{m}^{2}\right)\end{array}$ & $\begin{array}{c}\text { RS ( } \mathrm{n}^{\text {o }} \text { average } \\
\text { seed/ fruit) }\end{array}$ & $\begin{array}{c}\text { Fruit production } \\
* 100\end{array}$ & $\begin{array}{c}\text { FS (fruits/ flower) } \\
* 16.7\end{array}$ \\
\hline Patch 1 (WF) & 1.6 & $7.3 \pm 0.6$ & 3 & 0 \\
Patch 1 (CW) & 1.6 & $0.9 \pm 0.8$ & 0 & 61.1 \\
Patch 2 (WF) & 2.3 & $7.2 \pm 0.4$ & 5 & 27.8 \\
Patch 2 (CF) & 2.3 & $8.9 \pm 0.8$ & 11 & 77.8 \\
Patch 3 (WF) & 5.5 & $7.8 \pm 0.8$ & 10 & 55.6 \\
Patch 3 (CF) & 5.5 & $10.5 \pm 0.5$ & 6 & 27.8 \\
Patch 4 (WF) & 9.8 & $6.6 \pm 0.5$ & 5 & 33.3 \\
Patch 4 (CF) & 9.8 & &
\end{tabular}

Population density showed a significant effect on the total seeds produced per individual that produced fruits $\left(\mathrm{F}_{1,51}=27.4 ; \mathrm{p}<0.001\right)$. Nonetheless, whole flowers produced significantly greater number of seeds than cut flowers $\left(F_{1,51}=12.6 ; p<0.001\right)$. In whole flowers treatment the patches with high density were those with the greater seed production, in cut flowers treatment the opposite trend was observed (Fig. 1).

\section{DISCUSSION}

According to our results, the reproductive success of Nothoscordum gramineum significantly increases with the increase in the local density, which is in agreement with results reported in other studies (e.g., Roll et al. 1997, Bosch \& Waser 1999, Brys et al. 2004). Populations with high density of flowers would be easily perceived by pollinators (Kawarasaki \& Hori 1999), with those concentrating their forage activity in these populations where a great amount of resources can be found. This will allow pollinators to optimize their trade-off between cost of flight and benefit by ingestion of resources (Jennersten 1988; Klinkhamer \& Van der Lugt 2004).

Our results also indicate that the increase in cospecific individuals density produce a facilitation process in the reproductive success. However, this relationship between density and RS was not completely linear, because further increases in population density can produce intraspecific 
competition by pollinator as it has been shown in other studies (e.g., Bullock \& Martinez del Río 1989, Feldman et al. 2004). Other empirical studies have demonstrated that treatments with high density of flower received a greater number of pollinator visits, but this increase would not be proportional to the increase in the number of flowers, with some flowers remaining without visitation of pollinator (Geber 1985, Klinkhamer et al. 1989).

Flowers size, would be an important signal for pollination process, particularly in conditions of low density of flowers, since under this condition pollinators would discriminate between flowers of different sizes supporting the predictions of Cohen \& Shmida (1993) and Mitchell et al. (2004). When decreasing the size of flowers, these become less attractive for pollinators, being excluded from a possible choice by pollinators. Our results are in line with this prediction and with the studies of Cavieres et al. (1998) and Totland (2004) who have reported that flowers of large size have higher pollinator visitation rates. This preferential choice of large size flower could be due to the flower size is positively correlated with nectar rewards for pollinators (Cohen \& Shmida 1993).

Independently of the patch density, a greater amount of seeds is produced in whole flowers, suggesting that floral "display" would be a variable of higher hierarchy than density of flowers, in the "decision of forage" by pollinators. This suggests that pollinators would choose a patch with greater density of flowers, and once inside they could discriminate between flowers of different sizes. In the case of plots with lower density, the greater distance between flowers will demands a greater energetic cost in pollinator flights, generating a flower size discrimination by pollinators, with those preferring larger flowers in search of the greater rewards. Nevertheless, a decreasing of seed production in cut flowers treatment by effect of hand manipulation only, not is rule out here.

The reproductive success (RS) expressed as the average amount of seeds per plot, suggests an increase of RS with the increase of density. Nevertheless, maximum seed production occurred at different densities at each treatment (Fig. 1).

Although the present study provides valuable information about the effect of the density and floral traits on the reproductive success, the exploration of other variables such as water and nutrients availability at each plot, and cover of companion species could shed more lights about the ultimate determinants of the reproductive success of Nothoscordum gramineum in coastal evergreen forest of central Chile.

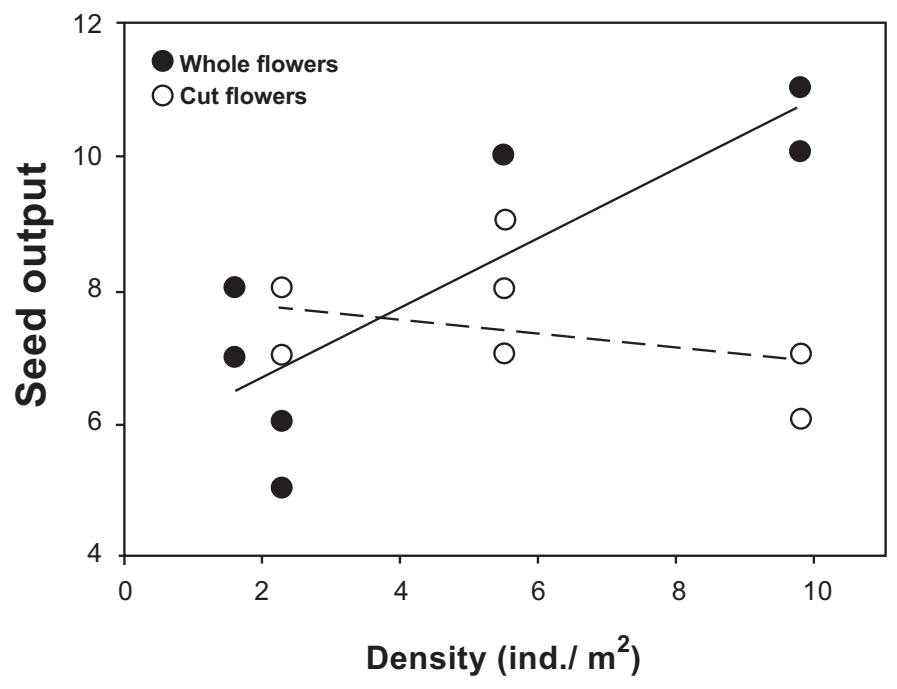

FIGURE 1. ANCOVA analysis that show the variation of reproductive success of Nothoscordum gramineum individuals that produced fruits with whole (solid circles) and cut (open circles) flowers in patches of different densities.

Figura 1. Análisis de co-variancia que muestra la variación del éxito reproductivo en individuos de Nothoscordum gramineum que produjeron frutos con flores enteras (círculos negros) y cortadas (círculos blancos) en parches de diferentes densidades. 
In conclusion, we found that the reproductive success of Nothoscordum gramineum increases with the density of flowers. Although in our study we only assessed one patch per density, it was evident that flower size is a signal of great importance in the process of biotic pollination, with the largest flowers being those that showed a higher reproductive success. The hypothesis that in high density patches flower sizes would have lower relevance in the decision of forage by pollinators, cannot be supported by our results since cut flowers showed similar levels of RS at all densities and significantly lower RS than their co-specifics of larger sizes. At low densities, flowers of large size would be a key attribute to attract pollinators; this is evident from the fact that cut flowers did not produce fruit at lower densities.

\section{ACKNOWLEDGMENTS}

Thanks to Mary T.K. Arroyo for her helpful suggestions and comments on an earlier version of the manuscript. D. Furman, L. Pouchuc and M. Landaeta, are acknowledged for their help in the field-work. Support from the 2005 BBVA Foundation Prize in Conservation Biology and F ICM 05 P02 is also acknowledged.

\section{BIBLIOGRAPHY}

Aizen, M.A \& P. Feinsinger. 1994. Forest fragmentation, pollination and plant reproduction in a Chaco dry forest, Argentina. Ecology 75: 330-351.

Bosch, M. \& N. Waser. 1999. Effects of local density on pollination and reproduction in Delphinium nuttallianum and Aconitum columbianus (Ranunculaceae). American Journal of Botany 86: 871-879.

Brys, R., Jacquemyn, H., Endels, P., van Rossums, F., Hermy, M., Triest, L., de Bruyns, L. \& G.D. BLust. 2004. Reduced reproductive success in small populations of the self-incompatible Primula vulgaris. Journal of Ecology 92: 514.

Bullock, S.H. \& C. Martinez del Rio. 1989. Bee visitation rates to trees of Prockia crucis differing in flower number. Oecologia 78: 389393.

Cavieres, L.A., Peñaloza, A. \& M.T.K. Arroyo. 1998. Effects of flower size and flower density on pollinator visitation in Alstroemeria pallida
Graham (Amaryllidaceae). Gayana Botánica 55: $1-10$.

Cohen, D. \& A. Shmida. 1993. The evolution of flower display and reward. Evolutionary Biology 27: 197-243.

Faegri, K. \& L. VAn Der PiJl. 1971. The Principles of Pollination Ecology. Pergamon Press, Oxford. $291 \mathrm{pp}$.

Feldman, T.S., Morros, W.F. \& W.G. Wilson. 2004. When can two plant species facilitate each other's pollination? Oikos 105: 197-212.

Geber, M.A. 1985. The relationship of plant size to selfpollination in Mertensia ciliata. Ecology 66: 762772.

Hoffmann, A. 1997. Flora silvestre de Chile. Ediciones Fundación Claudio Gay, Santiago, Chile. 258 pp.

Jennersten, O. 1988. Pollination in Dianthus deltoides (Caryophyllaceae): effects of habitat fragmentation on visitation and seed set. Conservation Biology 2: 359-366.

Kato, E. \& T. HiURA. 1999. Fruit set in Stryrax obassia (Styracaceae): the effect of light availability, display size, and local floral density. American Journal of Botany 86: 495-501.

KAWARASAKI, S. \& Y. HoRI. 1999. Effect of flower number on the pollinator attractiveness and the threshold plant size for flowering in Pertya triloba (Asteraceae). Plant Species Biology 14: 69-74.

Klinkhamer, P.G. \& P.P. van DeR Lugt. 2004. Pollinator service only depends on nectar production in sparse populations. Oecologia 140: 491-494.

Klinkhamer, P.G., DE Jong, T.J. \& G.J. De Bruyn. 1989. Plant size and pollinator visitation in Cynoglossum officinale. Oikos 54: 201-204.

Krannitz, P.G. \& M.A. Maun. 1991. An experimental study of floral display size and reproductive success in Virurnum opulus: the importance of grouping. Canadian Journal Botany 69: 394-99.

Mitchell, R.J., Karron, J.D., Holmquist, K.G. \& J.M. BELL. 2004. The influence of Mimulus ringens floral display size on pollinator visitation patterns. Functional Ecology 18: 116-124.

Neal, P.R., Dafni, A. \& M. Giurfa. 1998. Floral symmetry and its role in plant-pollinator systems: terminology, distribution, and hypotheses. Annual Review Ecological and Systematics 29: 345-373.

Pacala, S.W. \& J.A. Silander. 1990. Field tests of neighborhood population dynamic models of two annual weed species. Ecological Monographs 60: 113-134.

Polymeris, C. 1995. Vegetación actual de la Península de Hualpén: clasificación y dinámica. Tesis de Grado de Magíster en Ciencias, Mención Botánica, Universidad de Concepción, Concepción, Chile. $190 \mathrm{pp}$.

Robertson, A.W. \& M.R. Macnair. 1995. The effect of floral display size pollinator service to individual flower of Myosotis and Mimulus. Oikos 72: 106114. 
Gayana Bot. 63(1), 2006

Roll, J., Mitchell, R.J., Cabin R. \& D.L. Marshall. 1997. Reproductive success increases with local density of conespecifics in a desert mustard (Lesquerella fendleri). Conservation Biology 3: 738-746.

Roy, B.A. 1996. A plant pathogen influences pollinator behavior and may influence reproduction of nonhosts. Ecology 77: 2445-2457.
SUZUKI, N. 2003. Significance of flower exploding pollination on the reproduction of the Scotch broom, Cytisus scoparius (Leguminosae). Ecological Research 18: 223-232.

Totland, O. 2004. No evidence for a role of pollinator discrimination in causing selection on flower size through female reproduction. Oikos 106: 558-564.

Recibido 03.05.05

Aceptado 27.03.06 